\title{
An Evaluation of the Structural Integrity of the Polymer-Modified Cement Waste Form
}

\section{폴리머 시멘트 고화체에 대한 구조적 건전성 평가}

\author{
Young-Yong Jl1), Kyung-Kil KWAK, Dae-Seok HONG, Tae-Kuk KIM and Woo-Seog RYU \\ Korea Atomic Energy Research Institute, 1045 Daedeok-daero, Yuseong,Daejeon, Korea \\ 지영용1), 곽경길, 홍대석, 김태국, 류우석 \\ 한국원자력연구원, 대전시 유성구 대덕대로 1045
}

(Received March 18, 2011 / Revised May 03, 2011 / Approved June 14, 2011)

\begin{abstract}
Polymer-modified cement is the composite material made by partially replacing and strengthening the cement hydrate binders of conventional mortar with polymeric modifiers such as polymer latexes and redispersible polymeric modifiers. It is known that the addition of polymer to cement mortar leads to improved quality, which would be expected to have a high chemical resistance.Therefore, the purpose of this study is to identify the improved chemical resistance, such as low permeability and low ion diffusivity, of the polymermodified cement as a solidification agent for the radwaste. First, polymer-modified cement specimens by latex modification were prepared according to the polymer content from $0 \%$ to $30 \%$ to select the optimized polymer content. At those specimens, the water-to-cement $(\mathrm{W} / \mathrm{C})$ ratio was maintained to $33 \%$ and $50 \%$ respectively. After the much curing time, the structural integrity of specimens was evaluated through the compressive strength test and the porosity evaluation by the water immersion method. From the results, $10 \%$ of the polymer content at $33 \%$ of the $\mathrm{W} / \mathrm{C}$ ratio was shown to have the most improved quality. Finally, the leaching test referredfrom ANS 16.1 for the specimens having the most improved quality was conducted. Dedicated specimens for the leaching test were then mixed with radioisotopes of ${ }^{60} \mathrm{Co}$ and ${ }^{137} \mathrm{Cs}$ at the specimen preparation.
\end{abstract}

Key words : Polymer-modified cement, Integrity, Compressive strength, Porosity, Immersion, Leaching

\section{요 약}

폴리머 시멘트 고화체는 일반 몰타르 내의 시멘트 수화물을 폴리머 개질제를 이용하여 부분적으로 대 체함으로써 그 기능을 강화시킨 복합재로로써, 특히 시멘트 몰타르에 폴리머를 첨가하는 것은 그 화학적 내구성을 향상시킨다고 알려져 있다. 따라서 본 연구에서는 고화재료로서의 폴리머 시멘트에 대한 낮은 침투성 및 낮은 이온 확산도 둥과 같은 향상된 화학적 내구성을 확인하기 위하여 폴리머 시멘트 시편들을 제조하였다. 이때 폴리머의 함량은 0에서부터 $30 \%$ 까지 변화시켰으며, 물에 대한 시멘트 비 $(\mathrm{W} / \mathrm{C})$ 를 $33 \%$

1) Corresponding Author. E-mail : yyji@kaeri.re.kr 
와 $50 \%$ 로 각각 유지 시컸다. 충분히 경화시킨 후에, 제조된 시편들에 대한 구조적 건전성을 압축강도와 수침법에 의한 공극도를 통하여 평가하였다. 그 결과, W/C 비가 $33 \%$ 이고, 폴리머 함량이 약 $10 \%$ 인 폴리 머 시멘트 시편에서 가장 향상된 개질변화를 얻을 수 있었다. 끝으로 이 최적의 조합비를 가지는 시편에 대하여 ANS 16.1에 따르는 침출시험을 수행하였으며, 그 결과를 일반 시멘트 고화체와 비교하였다.

중심단어 : 폴리머 시멘트, 건전성, 압축강도, 공극도, 침수, 침출

\section{Introduction}

The Portland cement is a high performance material at the solidification matrix of the radwaste such as the concentrated waste from an evaporation process, because of the low material cost, the high mechanical strength, and a well-known process. However, some drawbacks of Portland cement still exist, due to its low tensile strength, the large drying shrinkage, and lastof all, its low chemical resistance.

In general, the bitumen matrix is selected as a solidification agent to make up for the weak points related to the chemical resistance in the Portland cement matrix. However, its strength is greatly decreased, because of the flexible characteristic of the bitumen itself. One of many attempts to improve the chemical resistance which make the strength of the Portland cement unchanged is to modify its quality by polymer additives such as latexes, redispersible polymer powders, water-soluble polymers, and so on [1-3]. An addition of the polymer to the Portland cement is known to have improved durability, low permeability, and low ion diffusivity.

In this study, the improved chemical resistance of polymer-modified cement with latex modification was evaluatedin order to ascertain the possible application as a solidification agent for the concentrated waste generated from the radioactive waste treatment facility at KAERI. The optimized polymer content in the cement pastes was first investigated through the evaluationof the compressive strength and the porosity. The structural integrity such as the leaching, the immersion, and the thermal cycling test was then evaluated for the polymer-modified cement having optimized polymer content at the water-to-cement ratio (W/C) of $33 \%$.

\section{Materials and Methods}

In order to select the optimized polymer content for the modification of the ordinary Portland cement (OPC) paste, the specimens modified by latex were prepared. And then, those properties related to the structural integrity were evaluated through the compressive strength and the porosity test.

\section{Specimens preparation}

The polymer-modified cement specimens by latex modification for the selection of the optimized polymer content in the Portlandcement were prepared according to the polymer content from $0 \%$ to $30 \%$. At those specimens, the $\mathrm{W} / \mathrm{C}$ ratio was maintained to $33 \%$ and $50 \%$ respectively and the diameter-to-length ratio of about 2 times was also maintained. Table 1 shows the specimens by the polymer content and Fig. 1 shows the processed specimens for the compressive strength test after 3 weeks of curing time.

\section{Determination of the Optimized Polymer Content}

(1) Compressive strength

In order to evaluate the strength variation of polymer-

Table 1. Specification of polymer-modified cement specimens

\begin{tabular}{|c|c|c|c|}
\hline \multicolumn{2}{|c|}{$* \mathrm{~W} / \mathrm{C}=0.50$} & \multicolumn{2}{c|}{$\mathrm{W} / \mathrm{C}=0.33$} \\
\hline Index & ${ }^{*} * \mathrm{P} / \mathrm{T}$ & Index & $\mathrm{PT}$ \\
\hline BT0 & 0.00 & CT0 & 0.00 \\
\hline BT1 & 0.14 & CT1 & 0.08 \\
\hline A1 & 0.17 & CT2 & 0.11 \\
\hline BT2 & 0.20 & CT3 & 0.14 \\
\hline BT3 & 0.25 & CT4 & 0.17 \\
\hline BT4 & 0.29 & CT5 & 0.20 \\
\hline
\end{tabular}

* W/C : water-to-cement ratio,

**PT : polymer-to-total mixture ratio 
modified cement with the polymer content, the compressive strength test was conducted for specimens every a week according the test procedure [4]. The results are shown in Fig. 2. Although the compressive strength decreased in proportion to increase of the polymer content, all specimens with the $\mathrm{W} / \mathrm{C}$ ratio of $33 \%$ and $50 \%$ were showed higher values than the waste acceptance criteria for the rigid matrix. Since the decreasing tendency of the compressive strength is not the exponential type but a sigmoidtype, it could be expected that the strength variation until about $10 \%$ of

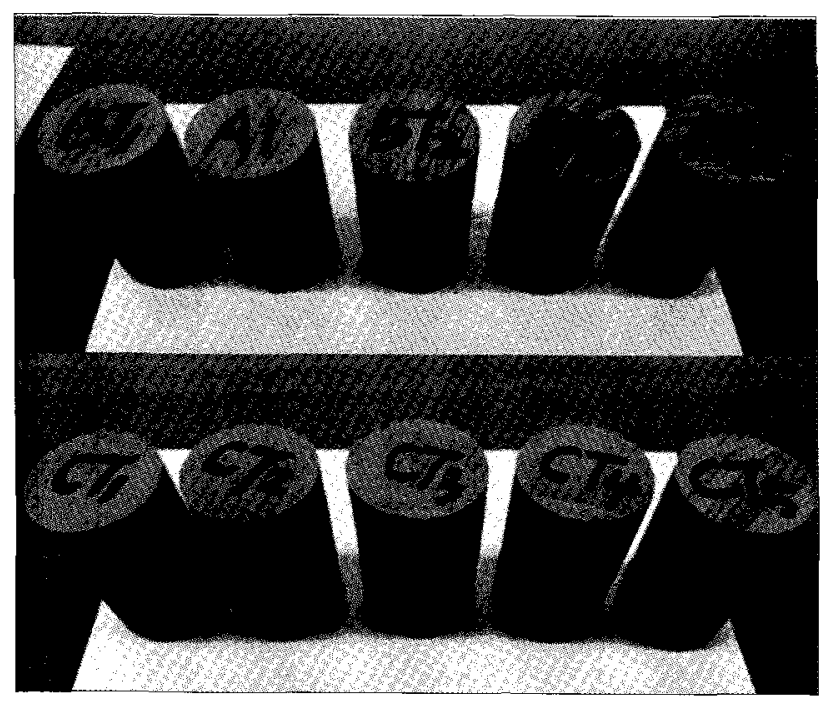

Fig. 1. Polymer-modified cement specimens for the compressive strength test

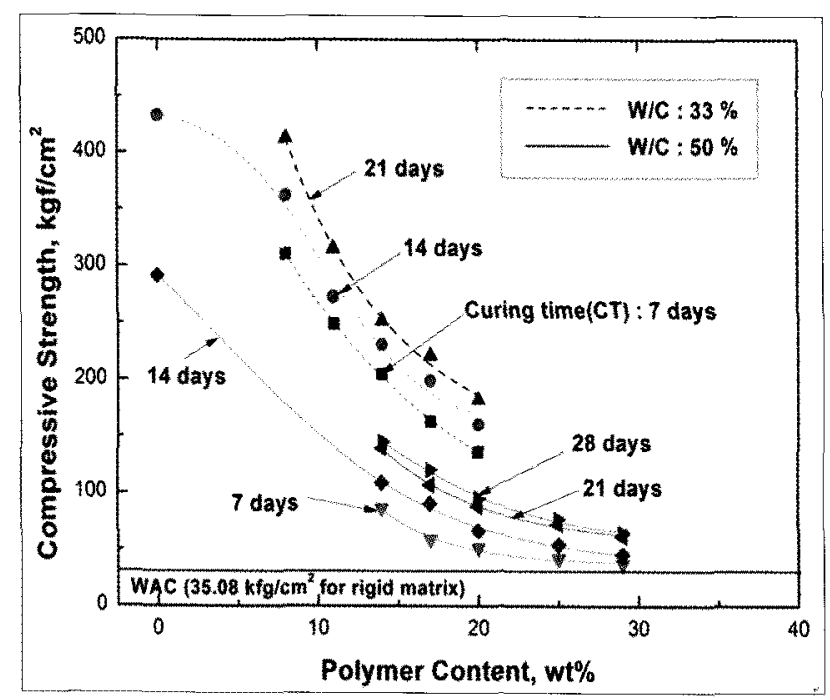

Fig. 2. Compressive strength test results for specimens according to the polymer content every a week of the curing time the polymer content is negligible as shown in the results on $33 \%$ of the $\mathrm{W} / \mathrm{C}$ ratio.

\section{(2) Porosity}

The porosity of hardened cement paste generally decreased with the polymer addition in attribution to the polymer emulsion filling the capillary pores. When total porosity inside the cement matrix is sufficiently small, it could be attained to high structural integrity such as high strength, low permeability, and low ion diffusivity.

First, samples for the porosity evaluation were prepared by cutting the specimens cured during 4 weeks into the size of about $1 \mathrm{~cm}^{3}$. The test was then conducted by water immersion method. The mathematical expression for water immersion method is as follows;

$$
\begin{gathered}
\rho_{d}=\frac{W_{d}}{V_{d}}=W_{d} \times \frac{\rho_{w}}{W_{s}-W_{w}} \\
P=1-\frac{\rho_{d}}{\rho_{t}}
\end{gathered}
$$

Where, $\rho_{d}$ and $\rho_{w}$ are the sample density in dry and in water, $\rho_{t}$ is the theoretical density by the material content, $W_{d}$ and $W_{w}$ are the sample weight in dry and in water, $W_{s}$ is the saturated weight by water, $V_{d}$ is the sample volume in dry, and $\mathrm{P}$ is the porosity.

The results on the porosity evaluation are shown in Fig. 3 . The porosity decreased with increase of the polymer content. A total $10-\%$ decrease of the porosity compared with the fresh Portland cement without the polymer addition was shown until about $20 \%$ of the polymer content both $33 \%$ and $50 \%$ of the W/C ratio. And then, the plateau which means the range with negligible difference of the porosity in spite of increasing the polymer content existed from $5 \%$ to $15 \%$ of the polymer content. Therefore, the optimized polymer content was determined as $8 \%$ of the polymer content that was not severe decrease of the compressive strength as shown in Fig. 2.

\section{Results and Discussions}

The characterization of the optimized polymer-modified cement was investigated through procedures for the 


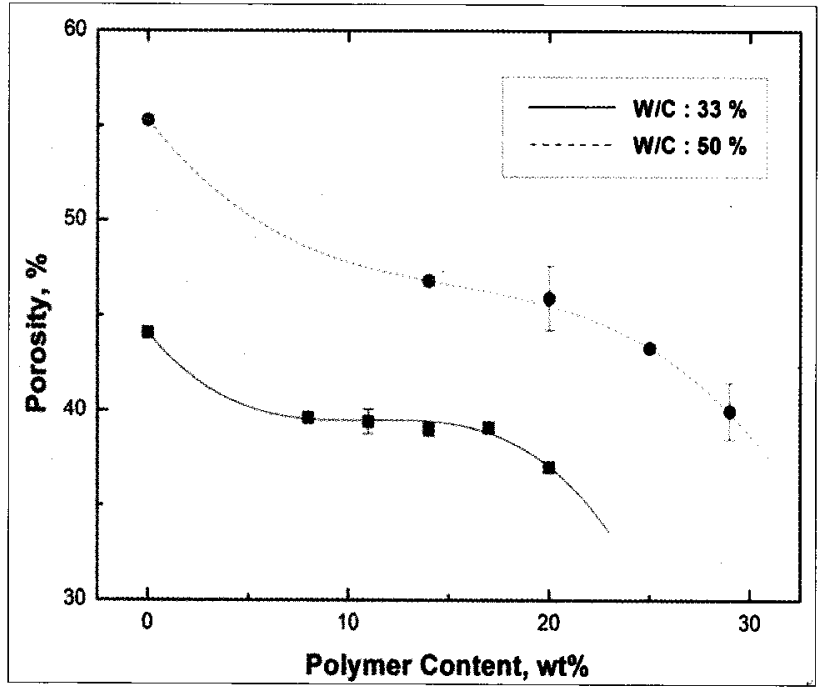

Fig. 3. Porosity of the polymer-modified cement with the difference of the polymer content.

compressive strength, the thermal cycling [5], the immersion [6], and the leaching test [7]. The specification of specimens for four tests was shown in table 2 . In the case of the leaching test, the radioisotopes such as ${ }^{60} \mathrm{Co}$ and ${ }^{137} \mathrm{Cs}$ with the radioactivity of about $10 \mu \mathrm{Ci}$ individually were inserted in the cement paste when mixing the demiwater with the Portlandcement. Since the volume reduction of about $20 \%$ existed at the cutting stage of specimens into the demanded sizes of each test procedures, the remained activity into a leaching specimen was expected to about $8 \mu \mathrm{Ci}$ individually. The manufacturing process of a leaching specimen was shown in Fig. 4.

\section{Thermal Cycling Test}

The thermal cycling test indicates the thermal

Table 2. Specimens on the structural integrity test for the optimized polymer-cement

\begin{tabular}{|c|c|c|c|c|c|}
\hline & Dia.(mm) & Height $(\mathrm{mm})$ & P/T & W/C & Nuclide \\
\hline \multirow{3}{*}{ *C.S. } & 50.1 & 101.2 & & & \\
& 50.1 & 100.5 & 0.08 & 0.33 & - \\
& 50.1 & 100.1 & & & \\
\hline \multirow{*}{*}{ *T.C } & 50.1 & 100.3 & & & \\
& 50.2 & 99.9 & 0.08 & 0.33 & - \\
& 50.1 & 99.5 & & & \\
$* * *$ I & 50.0 & 101.1 & & & - \\
& 50.2 & 100.4 & 0.08 & 0.33 & \\
\hline$* * *$ L & 50.1 & 102.3 & & & Co-60 (8uCi) \\
\hline
\end{tabular}

*Compressive strength test *** Thermal cycling test

**** Immersion test **** Leaching test resistance of the solidification agent according to the temperature variation. Depending onthe test procedure, the temperature variation for one cycle is from $-60{ }^{\circ} \mathrm{C}$ to $40{ }^{\circ} \mathrm{C}$ and total 30 cycles are conducted. After 30 cycles, the integrity of test specimens was evaluated through the compressive strength test. Therefore, the thermal resistance by the polymer addition could be anticipated at the polymer-modified cement suffered the temperature variation. The specimens in the test chamber are shown in Fig. 5. As compared with the results on the compressive strength test without the thermal cycling, the difference of the structural integrity before and after the thermal cycling was less than about $10 \%$.

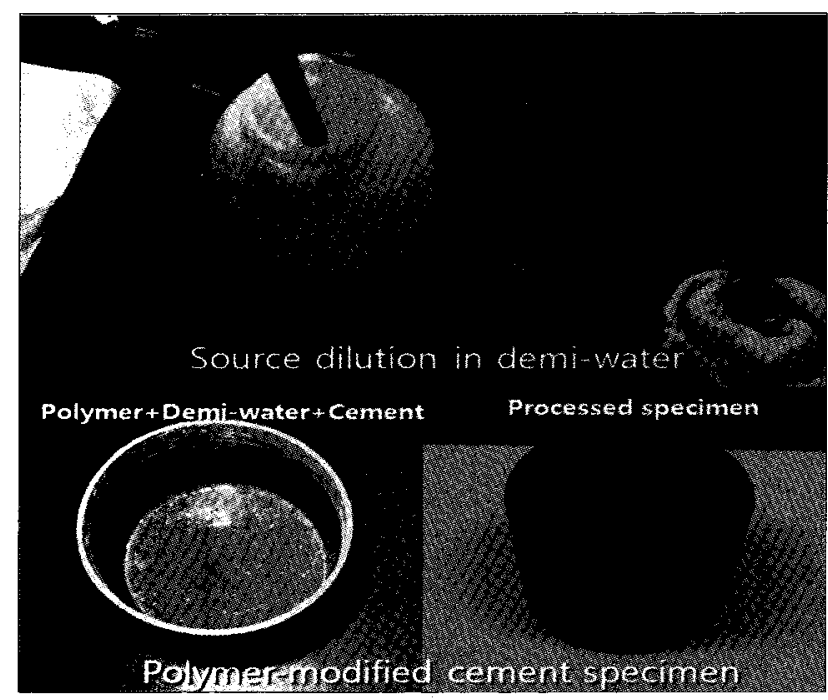

Fig. 4. The manufacture process of a leaching specimen.

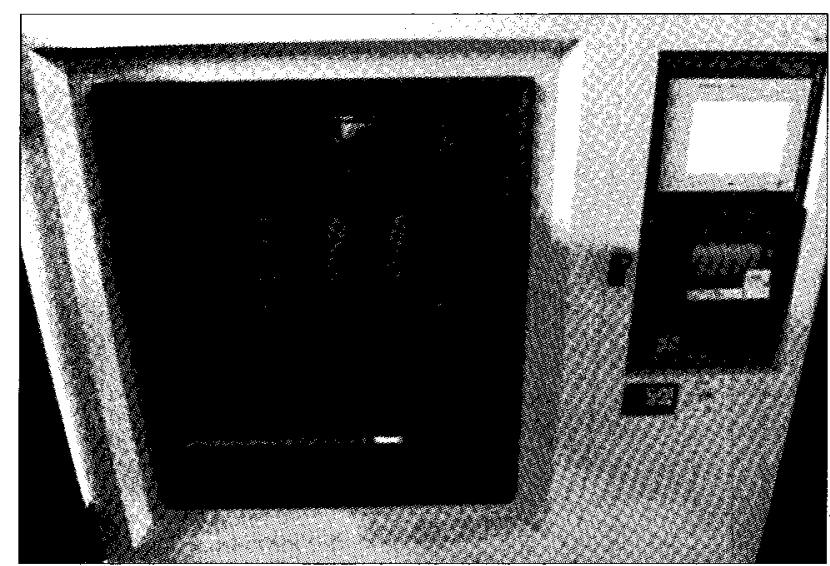

Fig. 5. The test specimens in the humidity and temperaturecontrolled chamber 


\section{Immersion Test}

The immersion test indicates the water resistance of the solidification agent. According to the test procedure, the test specimens are exposurein water for 90 days and then, the integrity of them are evaluated. Therefore, the water resistance by the polymer addition could be anticipated at the polymer-modified cement suffered immersion. In addition, at total immersion period, the leachate is sampled by the specified time. The specimens on the support and the immersion vessel are shown in Fig. 6.

During the total immersion period, cracks and destruction at specimens were not existed and also, the difference of the specimen weight before and after immersion was less than about 7\%. As shown in Fig. 7, although the $\mathrm{pH}$ and the electrical conductivity (EC) increased according to the immersion time, those degrees were small compared with the OPC. Especially, the EC for the polymer-modified cement was greatly reduced as adding the polymer to the OPC. This means the improved quality for the water resistance of the polymer-modified cement. After total immersion period of about 90 days, the result on the compressive strength test of these specimens were about $400 \mathrm{kgf} / \mathrm{cm}^{2}$, this value was about the $10-\%$ difference compared with specimens without the immersion.

\section{Leaching Test}

As this polymer-modified cement is used as a

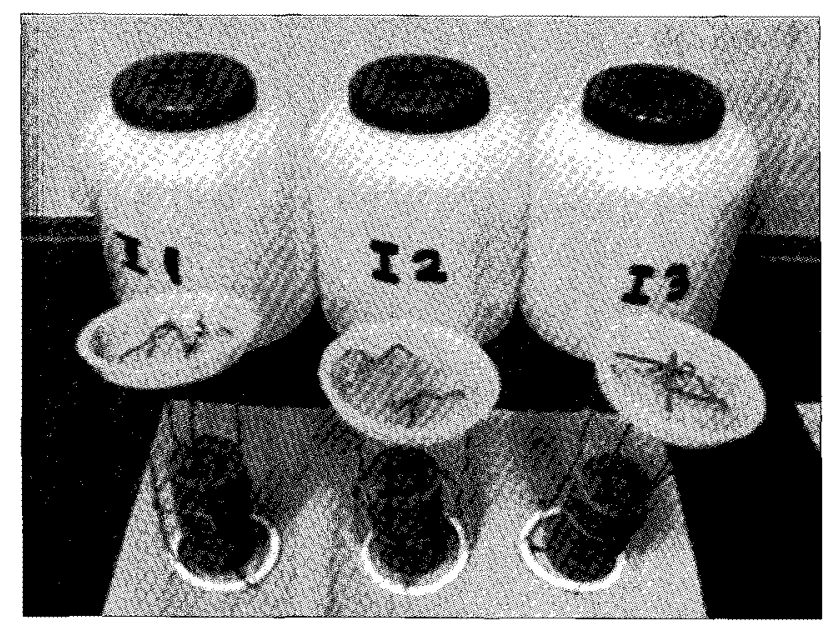

Fig. 6. The immersion specimens on the support and the immersion vessel. solidification agent for radwaste generatedfrom the nuclear facility, a diffusion degree of the nuclide was evaluated on the assumption that the solidified waste form was exposed into water according to the reference from ANS 16.1. During total leaching period of 5 days, the specimens were immersed into about $2650 \mathrm{~mL}$ of the leachant which consist of the demineralized water with 7.11 of the $\mathrm{pH}$ and $1.54 \mu \mathrm{S} / \mathrm{cm}$ of the EC. The leachates were then sampled every designated time interval and the leachant were entirely replaced after sampling. Sampled leachates into a 500 -mL cylindrical bottle were made the radiological analysis. From the radiological analyses, the incremental leaching rate and the leachability index for ${ }^{60} \mathrm{Co}$ and ${ }^{137} \mathrm{Cs}$ were calculated.

As shown in Fig. 8, the leaching rate for the nuclide of ${ }^{137} \mathrm{Cs}$ was higher than that of ${ }^{60} \mathrm{Co}$ at both cases. However the polymer-modified cement showed to relatively lower value compared with the OPC. In the case of the polymer-modified cement, after the leaching time of about 1 day, the value of the leaching rate at ${ }^{60} \mathrm{Co}$ was dropped to about 100 times $1^{\text {st }}$ leaching rate, and the value at ${ }^{137} \mathrm{Cs}$ was also dropped to about 10 times $1^{\text {st }}$ leaching time. That means the diffusivity of the nuclide within the polymer-modified cement media couldbe greatly decreased after just 1 day of the leaching, when compared with the OPC. And also, the leachability index was shown to 11.66 and 7.30 for ${ }^{60} \mathrm{Co}$ and ${ }^{137} \mathrm{Cs}$. The results on the leaching test for the polymer-modified

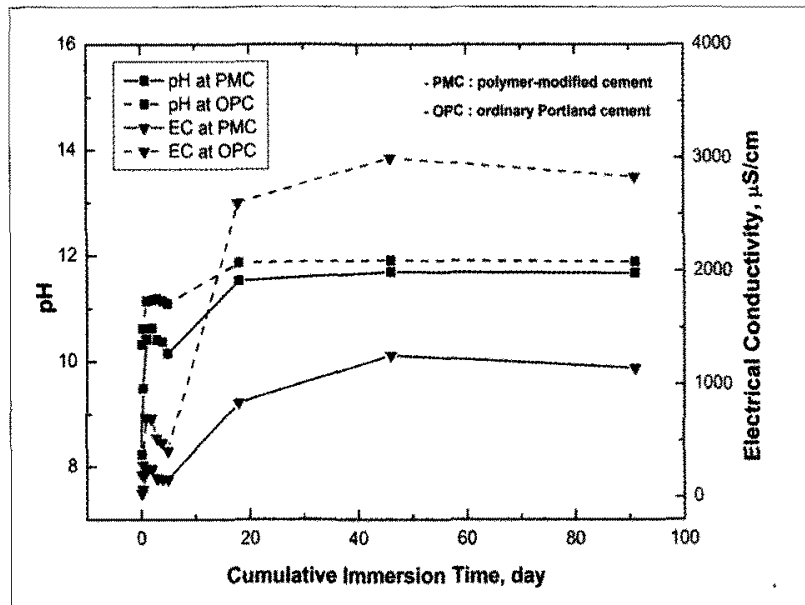

Fig. 7. $\mathrm{pH}$ and the electrical conductivity during the cumulative immersion time of 5 days. 


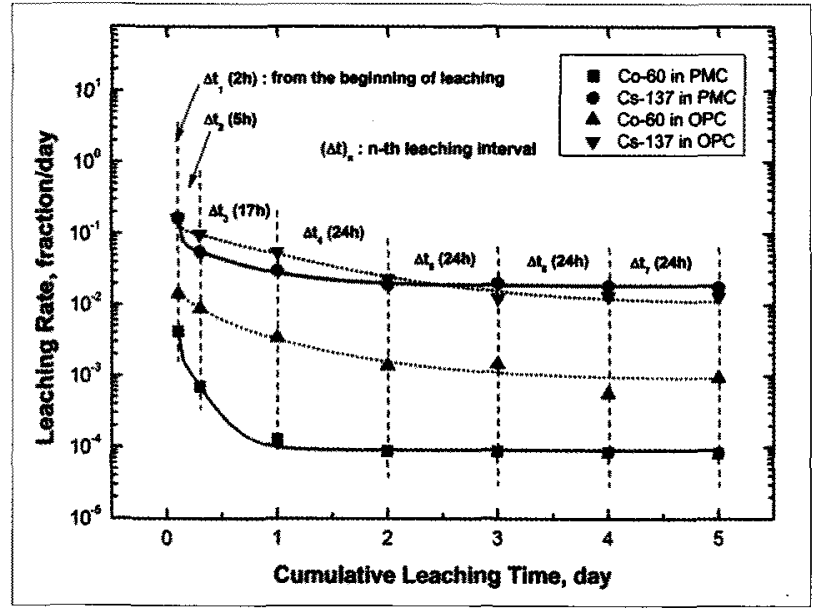

Fig. 8. The reaching rate during the cumulative leaching time of 5 days.

cement incorporated with the radioactive indictor demonstrated the satisfaction to the criteria, which demands above 6 for the leachability index, related to the nuclide diffusivity.

\section{Conclusions}

The polymer-modified Portland cement by the latex modification was investigated for possible application as a solidification agent having the improved water resistance. The optimized polymer content in the cement pastes was first investigated through the evaluation of the compressive strength and the porosity. From this preliminarystudy on the polymer addition, the optimized polymer content was determined as $8 \%$ of the total mixture of the polymermodified cement at the $\mathrm{W} / \mathrm{C}$ ratio of $33 \%$. The structural integrity such as the leaching, the immersion, and the thermal cycling test was then evaluated for the polymermodified cement having optimized polymer content at the W/C ratio of $33 \%$. As a result, the improved qualities of the polymer-modified cement compared with the OPC could be obtained at the chemical resistance related to the water resistance and the ion diffusivity.

\section{References}

[1] S. Chandra, Y. Ohama, "Polymers in Concrete", p. 81, CRC Press, Boca Raton, Florida (1994).
[2] J. T. Dikeou, D. W. Fowler, "Polymer Concrete Uses, Materials, and Properties", p. 261, American Concrete Institute, Detroit, Michigan (1985).

[3] H. Y. Yang and J. Y. Kim, "A Feasibility Study on the Polymer Solidification of Evaporator Concentrated Wastes", J. of the Korean Radioactive Waste Society, vol. 5(4) p297-308 (2007).

[4] RWTF, "Test procedure for the compressive strength of the rigid radwaste form", RWTF-TP-03, rev 2 (2008).

[5] RWTF, "Test procedure for the thermal cycling of the radwaste form", RWTF-TP-05, rev 3 (2008).

[6] RWTF, "Test procedure for the immersion of the radwaste form", RWTF-TP-06, rev 3 (2008).

[7] RWTF, "Test procedure for the leaching of the radwaste form", RWTF-TP-07 rev 1 (2008). 